BIBLIOTIKA : Jurnal Kajian Perpustakaan dan Informasi

Volume 3 Nomor 1, 2019

Journal homepage $:$ http://journal2.um.ac.id/index.php/bibliotika

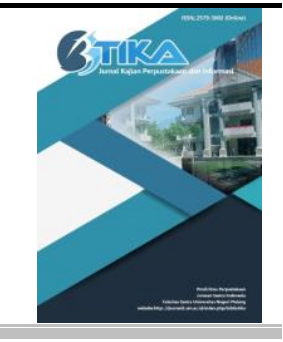

\title{
PENERAPAN HUKUM LOTKA PADA JURNAL ILMU SOSIAL DAN ILMU POLITIK (JSP) UNIVERSITAS GADJAH MADA
}

\author{
DNA Iftinan, Zulfa Avidiansyah, Rika Ayu Meilia ${ }^{*}$ \\ Sekolah Pascasarjana Universitas Gadjah Mada Yogyakarta
}

\begin{tabular}{|c|c|}
\hline $\begin{array}{l}\text { A R T I C L E } \\
\text { I N F O }\end{array}$ & A B S T R A C T \\
\hline $\begin{array}{l}\text { Article history: } \\
\text { Received: 2 Jan } 2019 \\
\text { Accepted: } 20 \text { Apr } 209 \\
\text { Published: } 31 \text { May } 2019 \\
\text { Keyword: } \\
\text { Hukum Lotka, jurnal } \\
\text { ilmu sosial dan ilmu } \\
\text { politik, produktivitas } \\
\text { jurnal. }\end{array}$ & $\begin{array}{l}\text { Lotka merupakan metode yang digunakan untuk menghitung } \\
\text { produktivitas penulis dalam suatu jurnal. Dalam penelitian ini, } \\
\text { produktivitas penulis dalam jurnal ilmu sosial dan ilmu politik milik } \\
\text { Fakultas Ilmu Sosial dan Ilmu Politik Universitas Gadjah Mada pada } \\
\text { tahun } 2016 \text { hingga } 2018 \text { dimana tiap volume/tahun terdapat } 6 \text { artikel } \\
\text { dengan jumlah penulis yang sangat variatif baik individu maupun } \\
\text { kelompok (lebihdari } 1 \text { orang). Pada jurnal Ilmu Sosial dan Ilmu } \\
\text { Politik (JSP) antara tahun } 2016 \text { hingga } 2018 \text { terdapat } 89 \text { nama } \\
\text { penulis. Hasil analisis diperoleh bahwa penulis yang paling produktif } \\
\text { menghasilkan } 2 \text { artikel dan yang paling sedikit menghasilkan } 1 \text { artikel } \\
\text { yang dimuat dalam jurnal tersebut. Langkah terakhir dalam } \\
\text { penerapan Hukum Lotka yakni menentukan uji Kolmonogrov- } \\
\text { Smirnov (Uji K-S). Uji K-S dilakukan terhadap persamaan Lotka. } \\
\text { Pada uji K-S menggunakan nilai kritis. Hasil dari perhitungan uji K- } \\
\text { S, diketahui jumlah penulis sebanyak } 89 \text { dan nilai deviasi maksimum } \\
\text { adalah 0,164. Uji Kolmogorov-Smirnov menentukan bahwa apabila } \\
\text { Dmaks lebih kecil dari nilai kritismaka tidak terdapat perbedaan yang } \\
\text { signifikan antara nilai teoritis dengan hasil pengamatan. Namun } \\
\text { sebaliknya, apabila Dmaks lebih besar dari nilai kritis, maka terdapat } \\
\text { perbedaan yang signifikan antara nilai teoritis dengan hasil } \\
\text { pengamatan. Jadi,berdasarkan hasil uji Kolmogorov-Smirnov } \\
\text { menghasilkan Dmaks = 0,164 dan nilai kritis 0,169.Sehingga hal } \\
\text { tersebut menunjukkan bahwa nilai Dmaks lebih kecil dari nilai kritis } \\
\text { dan dapat disimpulkan bahwa sesuai dengan Hukum Lotka. }\end{array}$ \\
\hline
\end{tabular}

Ilmu pengetahuan senantiasa berkembang sesuai dengan hakikat ilmu pengetahuan. Terutama pada saat ini dimana turut berkembangnya teknologi informasi, komunikasi, dan peradaban manusia dapat mendorong percepatan perkembangan ilmu pengetahuan. Pengembangan suatu ilmu pengetahuan tidak lepas dari peran para peneliti dalam meneliti bidang tersebut. Penelitian-penelitian tersebut kemudian dipublikasi agar dapat bermanfaat bagi bidang ilmu tersebut maupun penelitian selanjutnya (Tarigan, 2017).

\footnotetext{
* Corresponding author.

E-mail addresses: rikaayu94@mail.ugm.ac.id (Rika Ayu Meilia)
}

ISSN : 2579-3802 (Online) - BIBLIOTIKA : Jurnal Kajian Perpustakaan dan Informasi is licensed under Creative Commons Attribution-ShareAlike 4.0 International License (http://creativecommons.org/licenses/BY/4.0/). 
"Salah satu media yang dijadikan sebagai sarana komunikasi bagi semua kalangan baik masyarakat ilmiah maupun masyarakat umum adalah majalah/jurnal ilmiah. Karena informasinya yang selalu mutakhir, majalah/jurnal ilmiah menjadi salah satu sarana terpenting dalam mendukung perkembangan ilmu pengetahuan". Menurut Rifai (2001) jurnal adalah "terbitan berkala yang berbentuk pamflet berseri berisi bahan yang sangat diminati orang saat diterbitkan" (Wahyudi, 2015).

\section{Tinjauan Literatur}

\section{Hukum Lotka}

Metode ini diperkenalkan oleh Alfred James Lotka pada tahun 1929 yang meneliti produktivitas penulis dalam bidang Kimia dan Fisika. Produktivitas penulis ini disebut juga dengan produktivitas ilmiah (Pattah, 2013). "Percobaan untuk menguji penerapan Hukum Lotka pada disiplin ilmu lain baru banyak dilakukan sejak tahun 1973 dan terungkap bahwa tidak selamanya Hukum Lotka bisa diterapkan. Pada disiplin ilmu tertentu atau cara pengumpulan data menentukan apakah Hukum Lotka bisa digunakan atau tidak. Tahun 1974 Voos menyatakan pada subjek information science, rasionya adalah $1 / \mathrm{n}^{3.5}$. Untuk menguji apakah hukum Lotka dapat digunakan pada sekelompok data tertentu biasanya digunakan uji K-S atau uji KolmogorovSmirnov (the Kolmogorov-Smirnov Test). Salah satu instrumen uji statistik dengan metode nonparametrik adalah uji K-S ini. Instrumen uji statistik digunakan untuk mengetahui perbedaan yang nyata (signifikan) antara distribusi frekuensi pengamatan dengan distribusi frekuensi teoritis" (Mustafa, 2009).

\section{METODE}

Metode yang akan digunakan dalam penelitian Hukum Lotka ini adalah metode kuantitatif. Di mana nantinya akan dihitung produktivitas penulis dalam jurnal ilmu sosial dan ilmu politik milik Fakultas Ilmu Sosial dan Ilmu Politik Universitas Gadjah Mada. Pada penelitian ini penelitian berfokus pada jurnal terbitan tahun 2016-2018. Pada tahun 2016-2018 terdapat 89 nama penulis yang ada pada jurnal ilmu sosial dan ilmu politik.

\section{HASIL DAN PEMBAHASAN}

Menganalisa dengan menerapkan Hukum Lotka dapat digunakan untuk mengetahui tinggi rendahnya produktivitas kepengarangan pada jurnal/majalah ilmiah. Hukum Lotka merupakan sebuah hukum yang menghitung distribusi produktivitas penulis. Penerapan Hukum Lotka dapat digunakan pada Jurnal Ilmu Sosial dan Ilmu Politik (JSP) Universitas Gadjah Mada pada tahun 2016 hingga 2018 di mana tiap volume/tahun terdapat 6 artikel dengan jumlah penulis yang sangat variatif baik individu maupun kelompok (lebih dari 1 orang).

Berikut ini merupakan langkah-langkah dalam melakukan penerapan Hukum Lotka pada Jurnal Ilmu Sosial dan Ilmu Politik (JSP) Universitas Gadjah Mada tahun 2016 - 2018:

1. Menentukan pola produktivitas penulis dengan menggunakan Hukum Lotka dengan langkahlangkah seperti berikut:

a. Menentukan nilai partisipasi penulis dengan teknik Complete Count.

b. Menentukan nilai-nilai pendugaan parameter hukum Lotka (parameter $\mathrm{n}$ dan $\mathrm{C}$ ). Menurut Sulistyo Basuki dalamWahyudi (2015) untuk menentukan nilai 'terbaik' bagi n dan C dalam pengujian kesahihan Hukum Lotka, teknik terbaik yang dapat digunakan adalah Teknik 3, di mana:

$\mathrm{n}=\mathrm{N} \sum \mathrm{XY}-\sum \mathrm{X} \sum \mathrm{Y} / \mathrm{N} \sum \mathrm{X}^{2}-\left(\sum \mathrm{X}\right)^{2}$ dan $\mathrm{C}=\frac{1}{\sum \frac{1}{x^{n}}}$

c. Menghitung distribusi teoritis Hukum Lotkadengan persamaan yang digunakan adalahY $\mathrm{x}_{\mathrm{x}}=$ $\mathrm{C} / \mathrm{x}^{\mathrm{n}}$

2. Menguji Hukum Lotka dengan menggunakan Uji Kolmogorov-Smirnov 


\section{Menentukan Pola Produktivitas Penulis dengan Menggunakan Hukum Lotka Menentukan Nilai Partisipasi Penulisdengan Teknik Complete Count}

Teknik Complete Count merupakan sebuah teknik yang menghitung setiap kemunculan penulis. Kemunculan penulis diakui dan diterima dengan mendapatkan perlakuan yang sama, terlepas dari jumlah penulisterkait dengan artikel tersebut (Andres, 2009). Pada jurnal Ilmu Sosial dan Ilmu Politik (JSP) antara tahun 2016 hingga 2018 terdapat 89 nama penulis.

Tabel 1.1 Produktivitas Penulis

\begin{tabular}{|c|c|c|}
\hline No & Nama & $\begin{array}{c}\mathrm{F} \\
\text { muncul }\end{array}$ \\
\hline 1 & Indri Dwi Apriliyanti & 2 \\
\hline 2 & Tauchid Komara Yuda & 2 \\
\hline 3 & Adi Joko Purwanto & 1 \\
\hline 4 & Adiwan F. Aritenang & 1 \\
\hline 5 & Ahmed Fernanda Desky & 1 \\
\hline 6 & Ambar Widaningrum & 1 \\
\hline 7 & Andi Ahmad Yani & 1 \\
\hline 8 & Andi Yudha Yunus & 1 \\
\hline 9 & Anna Yulia Hartati & 1 \\
\hline 10 & Arif Novianto & 1 \\
\hline 11 & Arif Rianto Budi Nugroho & 1 \\
\hline 12 & Arina Rohmatul Hidayah & 1 \\
\hline 13 & Asrinaldi Asrinaldi & 1 \\
\hline 14 & Aulia Hadi & 1 \\
\hline 15 & Awan Santosa & 1 \\
\hline 16 & Bambang Arianto & 1 \\
\hline 17 & Barbara Allen & 1 \\
\hline 18 & Bertolomeus Loji Sua & 1 \\
\hline 19 & Bevaola Kusumasari & 1 \\
\hline 20 & Budi Irawanto & 1 \\
\hline 21 & Cahyo Pamungkas & 1 \\
\hline 22 & Desintha Dwi Asriani & 1 \\
\hline 23 & Diah Kusumaningrum & 1 \\
\hline 24 & Didik G. Suharto & 1 \\
\hline 25 & Dondick Wicaksono Wiroto & 1 \\
\hline 26 & Eko Teguh Paripurno & 1 \\
\hline 27 & Frans Gana & 1 \\
\hline 28 & Geovani Meiwanda & 1 \\
\hline 29 & Geraldino A. Sayd & 1 \\
\hline 30 & Gilang Desti Parahita & 1 \\
\hline 31 & Hani Noor Ilahi & 1 \\
\hline 32 & Hapsawati Taan & 1 \\
\hline
\end{tabular}




\begin{tabular}{|c|c|c|}
\hline No & Nama & $\begin{array}{c}\mathbf{F} \\
\text { muncul }\end{array}$ \\
\hline 33 & Haryanto Haryanto & 1 \\
\hline 34 & Haslinda B. Anriani & 1 \\
\hline 35 & Hayat & 1 \\
\hline 36 & Hempri Suyatna & 1 \\
\hline 37 & Hendrikus Hironimus Botha & 1 \\
\hline 38 & Hermin Indah Wahyuni & 1 \\
\hline 39 & Hieronymus Soerjatisnanta & 1 \\
\hline 40 & Indro Adinugroho & 1 \\
\hline 41 & Istianto Ari Wibowo & 1 \\
\hline 42 & Judotens Budiarto & 1 \\
\hline 43 & Komang Jaka Ferdian & 1 \\
\hline 44 & Li Li Pang & 1 \\
\hline 45 & Linda Dwi Eriyanti & 1 \\
\hline 46 & Lukman Kurniawan & 1 \\
\hline 47 & Lunyka Adelina Pertiwi & 1 \\
\hline 48 & Luthfi Makhasin & 1 \\
\hline 49 & M. Faishal Aminuddin & 1 \\
\hline 50 & Masduki Masduki & 1 \\
\hline 51 & Morissan Morissan & 1 \\
\hline 52 & Muba Simanihuruk & 1 \\
\hline 53 & Muhammad Iqbal Latief & 1 \\
\hline 54 & Muhammad Thaufan Arifuddin & 1 \\
\hline 55 & Nila Sastrawati & 1 \\
\hline 56 & Nopirin & 1 \\
\hline 57 & Nur Azizah & 1 \\
\hline 58 & Nurul Safitri & 1 \\
\hline 59 & Pahrudin HM & 1 \\
\hline 60 & Petrus Kase & 1 \\
\hline 61 & Pradhikna Yunik Nurhayati & 1 \\
\hline 62 & Pratiwi Utami & 1 \\
\hline 63 & Prima Nurita Rusmaningsih & 1 \\
\hline 64 & Puji Lestari & 1 \\
\hline 65 & Pujiati Pujiati & 1 \\
\hline 66 & Puthut Indroyono & 1 \\
\hline 67 & Rahmatiah Rahmatiah & 1 \\
\hline 68 & Rasyid Thaha & 1 \\
\hline 69 & Retno Kusumastuti & 1 \\
\hline 70 & Ria Manurung & 1 \\
\hline 71 & Rina Herlina Haryanti & 1 \\
\hline 72 & Rindu Sanubari Mashita Firdaus & 1 \\
\hline 73 & Rizabuana Ismail & 1 \\
\hline 74 & Rizky Alif Alvian & 1 \\
\hline
\end{tabular}




\begin{tabular}{|r|l|c|}
\hline No & \multicolumn{1}{|c|}{ Nama } & $\begin{array}{c}\text { F } \\
\text { muncul }\end{array}$ \\
\hline 75 & Robi Cahyadi Kurniawan & 1 \\
\hline 76 & Roby Muhamad & 1 \\
\hline 77 & Samodra Wibawa & 1 \\
\hline 78 & Smitha Sjahputri & 1 \\
\hline 79 & Suci Lestari Yuana & 1 \\
\hline 80 & Sudarmadji & 1 \\
\hline 81 & Sugiarto Pramono & 1 \\
\hline 82 & Suharko & 1 \\
\hline 83 & Suzanna Eddyono & 1 \\
\hline 84 & Tadzkia Nurshafira & 1 \\
\hline 85 & Wardiyanta & 1 \\
\hline 86 & Wasisto Raharjo Jati & 1 \\
\hline 87 & Widodo Agus Setianto & 1 \\
\hline 88 & Winengan & 1 \\
\hline 89 & Yogi Suprayogi Sugandi & 1 \\
\hline
\end{tabular}

Hasil analisis diperoleh bahwa penulis yang paling produktif menghasilkan 2 artikel dan yang paling sedikit menghasilkan 1 artikel yang dimuat dalam jurnal tersebut. Pada tabel 1.1 menunjukkan data penulis artikel dalam Jurnal Ilmu Sosial dan Ilmu Politik (JSP) Universitas Gadjah Mada tahun 2016 - 2018. Rincian hasil perhitungan produktivitas penulis dalam Jurnal Ilmu Sosial dan Ilmu Politik (JSP) Universitas Gadjah Mada selama tahun2016 hingga 2018 dapat dilihat pada tabel 1.3.

Tabel 1.2 Produktivitas PenulisArtikelJurnal JSP

\begin{tabular}{|c|c|c|}
\hline No & Jumlah Artikel (x) & $\begin{array}{c}\text { Jumlah Penulis } \\
(\mathbf{y})\end{array}$ \\
\hline 1 & 1 & 87 \\
\hline 2 & 2 & 2 \\
\hline
\end{tabular}

\section{Menentukan Nilai Pendugaan Parameter Hukum Lotka (Parameter n dan C)}

Pada langkah selanjutnya, parameter $\mathrm{n}$ dan $\mathrm{C}$ perlu diketahui nilainya. Menentukan nilainilai pendugaan parameter Hukum Lotka (parameter $\mathrm{n}$ dan $\mathrm{C}$ ) dapat menggunakan persamaan $\mathrm{n}$

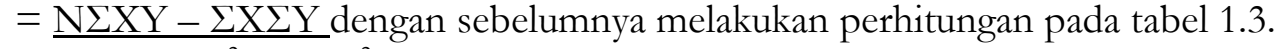

$$
\begin{aligned}
& \mathrm{N} \sum \mathrm{X}^{2}-\left(\sum \mathrm{X}\right)^{2} \\
& \mathrm{n}=\frac{\mathrm{N} \sum \mathrm{XY}-\sum \mathrm{X} \sum \mathrm{Y}}{\mathrm{N} \sum \mathrm{X}^{2}-\left(\sum \mathrm{X}\right)^{2}} \\
& =\frac{2 \cdot 0,09-0,031 \cdot 1,24}{2 \cdot 0,09-(0,301)^{2}} \\
& =\underline{0,18-0,37} \\
& =0,18-0,09 \\
& =-\underline{0,19} \\
& 0,09
\end{aligned}
$$


Tabel 1.3 Perhitungan untuk Menduga Parameter C

\begin{tabular}{|c|c|c|c|}
\hline No & Jumlah Artikel (x) & $\mathbf{x}^{\mathbf{n}}$ & $\mathbf{1 / \mathbf { x } ^ { \mathbf { n } }}$ \\
\hline 1 & 1 & 1 & 1 \\
\hline 2 & 2 & 4,32 & 0,23 \\
\hline \multicolumn{4}{|c|}{$\sum\left(1 / \mathrm{x}^{\mathrm{n}}\right)=1,23$} \\
\hline
\end{tabular}

Berdasarkan hasil perhitungan dugaan parameter $\mathrm{n}$ dan $\mathrm{C}$ dapat diketahui bahwa nilai $\mathrm{n}=$ 2,11 dan $C=0,813$.

Menghitung Distribusi Teoritis Hukum Lotka

Menghitung distribusi teoritis Hukum Lotka persamaan yang digunakan adalahY $\mathrm{x}_{\mathrm{x}}=\mathrm{C} / \mathrm{x}^{\mathrm{n}}$

Tabel 1.4 Hasil Perhitungan Nilai Produktivitas Penulis dan Distribusi Teoritis Hukum Lotka

\begin{tabular}{|c|c|c|c|c|c|c|c|c|c|c|}
\hline $\mathbf{X}$ & $\mathbf{y}_{\mathbf{x}}$ & $\begin{array}{c}\mathbf{X}= \\
\mathbf{l g} \mathbf{x}\end{array}$ & $\begin{array}{c}\mathbf{Y}=\mathbf{l g} \\
\mathbf{y}\end{array}$ & $\mathbf{X}^{2}$ & $\mathbf{X Y}$ & $\mathbf{y}_{\mathbf{x}} / \Sigma \mathbf{y}_{\mathbf{x}}$ & $\boldsymbol{\Sigma}\left(\mathbf{y}_{\mathbf{x}} / \Sigma \mathbf{y}_{\mathbf{x}}\right)$ & $\mathbf{F e}$ & $\boldsymbol{\Sigma} \mathbf{f e}$ & $\mathbf{D}$ \\
\hline 1 & 87 & 0 & 1,939 & 0 & 0 & 0,977 & 0,977 & 0,813 & 0,813 & 0,164 \\
\hline 2 & 2 & 0,301 & 0,301 & 0,09 & 0,09 & 0,022 & 0,999 & 0,188 & 1,001 & $-0,002$ \\
\hline$\Sigma$ & 89 & 0,301 & 1,24 & 0,09 & 0,09 & & & & & \\
\hline
\end{tabular}

$$
\begin{aligned}
\mathrm{Fe} & =\mathrm{C} / \mathrm{x}^{\mathrm{n}} \\
& =0,813 / 1^{2,11} \\
& =0,813 \\
\mathrm{Fe} & =\mathrm{C} / \mathrm{x}^{\mathrm{n}} \\
& =0,813 / 2^{2,11} \\
& =0,813 / 4,32 \\
& =0,188 \\
\mathrm{D} & =\left|\sum\left(\mathrm{y}_{\mathrm{x}} / \sum \mathrm{y}_{\mathrm{x}}\right)-\sum \mathrm{fe}\right| \\
& =0,977-0,813 \\
& =0,164
\end{aligned}
$$

\section{Uji Kolmogorov-Smirnov}

Langkah terakhir dalam penerapan Hukum Lotka yakni menentukan uji KolmonogrovSmirnov (Uji K-S). Uji K-S dilakukan terhadap persamaan Lotka. Pada uji K-S menggunakan nilai kritis. Hasil dari perhitungan uji K-S, diketahui jumlah penulis sebanyak 89 dan nilai deviasi maksimum adalah 0,164 (apabila terdapat nilai minus dapat diabaikan). Untuk mencari nilai kritis dapat dicari dengan menggunakan persamaan

$$
\text { c.v } \left.\left.=\frac{1,63}{(\Sigma y}+\Sigma y / 10\right)^{1 / 2}\right)^{1 / 2}
$$

Berikut adalah perhitungannya :

$$
\begin{aligned}
\text { c.v } & =\frac{1,63}{\left(\sum y+\left(\sum y / 10\right)^{1 / 2}\right)^{1 / 2}} \\
& =\frac{1,63}{\left(89+(89 / 10)^{1 / 2}\right)^{1 / 2}} \\
& =\frac{1,63}{(89+2,98)^{1 / 2}} \\
& =\quad \frac{1,63}{9,59} \\
& =0,169
\end{aligned}
$$

6 | BIBLIOTIKA : Jurnal Kajian Perpustakaan dan Informasi 
Jadi, hasil penghitungan menunjukkan bahwa nilai kritis adalah 0,169.

\section{SIMPULAN}

Uji Kolmogorov-Smirnov menentukan bahwa apabila Dmaks lebih kecil dari nilai kritismaka tidak terdapat perbedaan yang signifikan antara nilai teoritis dengan hasil pengamatan. Namun sebaliknya, apabila Dmaks lebih besar dari nilai kritis, maka terdapat perbedaan yang signifikan antara nilai teoritis dengan hasil pengamatan. Jadi,berdasarkanhasil uji KolmogorovSmirnov menghasilkan Dmaks $=0,164$ dan nilai kritis 0,169.Sehinggahaltersebut menunjukkan bahwa nilai Dmaks lebih kecil dari nilai kritis dan dapat disimpulkan bahwa sesuai dengan Hukum Lotka.

\section{DAFTAR PUSTAKA}

Andes, A. (2009). Measuring Academic Research: How to Undertake a Bibliometric Study. Oxford: Chandos Publishing.

Rifai, MA. (2001). Pegangan Gaya Penulisan, Penyuntingan, dan Penerbitan Karya Ilmiah Indonesia. Yogyakarta: Universitas Gadjah Mada.

Mustafa, B. (2009). "Hukum Lotka Mengenai Produktifitas Pengarang", diakses pada tanggal 19 Maret 2019 dari https://docplayer.info/39233505-Hukum-lotka-mengenai-produktifitaspengarang-oleh-b-mustafa-dan.html

Pattah, S. H. (2013). Pemanfaatan Kajian Bibliometrika Sebagai Metode Evaluasi dan Kajian dalam Ilmu Perpustakaan dan Informasi. Jurnal Khizanah Al-Hikmah. Vol. 1 No. 1: 47-57

Tarigan, A. K. (2017). Produktivitas Pengarang Menggunakan Hukum Lotka dengan Menggunakan Pendekatan Adjusted Count pada Jurnal Molecular Systems Biology pada Tahun 2007-2016. Skripsi, Universitas Sumatera Utara.

Wahyudi, A. (2015). Analisis Pola Produktivitas Penulis Artikel Bidang Perpustakaan dan Informasi di Indonesia: Suatu Kajian Bibliometrika. Tesis, Sekolah Pascasarjana Institut Pertanian Bogor. 